\title{
GEREJA DAN KEMISKINAN: DISKURSUS PERAN GEREJA DI TENGAH KEMISKINAN
}

\author{
Fibry Jati Nugroho \\ Sekolah Tinggi Teologi Sangkakala \\ Jl. Raya Kopeng, Pijil, Sumogawe, Getasan, Semarang, Jawa Tengah 50774 \\ Email: fibryjatinugroho@gmail.com
}

\begin{abstract}
Fibry Jati Nugroho, Church and Poverty: Discourse on the Role of the Church in the Midst of Poverty. The problem of poverty is not only a local problem, but a problem that the world is struggling with. The Church as the Lord's mandate in the middle of the world, is required to play a role in helping the problem of poverty. How naturally does the church play a role in the midst of community poverty? By using descriptive analysis methods, and in conjunction with the thinking of Karl Marx, examine the role of the church in helping to overcome the problem of poverty. The church's calling should be to voice injustice and oppression of poor people's rights. The Church is present to side with the weak, the powerless, the poor, and the marginalized. If the church does not have partiality to the weak, then the presence of the church has no meaning. The church needs to continually offer its prophetic criticism indiscriminately against various abuses of power, the occurrence of injustice, the deprivation of public rights, and the oppressive and impoverishing system of humans. The spirituality and religiosity of the congregation must also come to a social piety, in which the spiritual energy possessed by the congregation is able to encourage concern for various problems in people's lives. Spirituality like this must be a concern of the church in building the life of the church. The cross must be understood as a reflection of the suffering and death of Christ, but at the same time must be able to open the eyes and ears of suffering, misery, and human hope for their dignity and human dignity. That's where the church plays a role.
\end{abstract}

Keyword: Church, Poverty, Karl Marx, Spirituality

Abstrak: Fibry Jati Nugroho, Gereja dan Kemiskinan: Diskursus Peran Gereja di Tengah Kemiskinan. Permasalahan kemiskinan bukan hanya menjadi masalah lokal, namun menjadi masalah yang digumulkan oleh dunia. Gereja sebagai mandataris Tuhan di tengah dunia, dituntut untuk dapat berperan dalam membantu masalah kemiskinan. Bagaimanakah sewajarnya gereja berperan di tengah kemiskinan masyarakat? Dengan menggunakan metode deskriptif analisis, serta meminjam pemikiran Karl Marx, untuk menelisik peran gereja dalam membantu mengatasi permasalahan kemiskinan. Panggilan gereja yang seharusnya adalah untuk menyuarakan ketidakadilan dan penindasan hak-hak orang miskin. Gereja hadir untuk berpihak kepada yang lemah, tidak berdaya, miskin, dan yang terpinggirkan. Jika gereja tidak memiliki keperpihakan kepada yang lemah, maka kehadiran gereja tidak memiliki makna. Gereja perlu terus menerus menyuarakan kritik profetisnya tanpa pandang bulu terhadap berbagai penyalahgunaan kekuasaan, terjadinya ketidakadilan, terampasnya hak-hak masyarakat, dan terhadap sistim yang menindas serta memiskinkan manusia. Spiritualitas dan religiusitas jemaat juga harus sampai kepada sebuah kesalehan sosial, di mana energi spiritual yang dimiliki jemaat mampu untuk mendorong kepeduliannya akan berbagai persoalan kehidupan masyarakat. Spiritualitas seperti inilah yang harus menjadi perhatian gereja dalam membangun kehidupan jemaat. Salib harus dipahami sebagai refleksi atas penderitaan dan kematian Kristus, namun di saat yang sama pula harus mampu membuka mata dan telinga akan penderitaan, kesengsaraan, dan pengharapan manusia akan harkat dan martabatnya sebagai manusia. Disitulah gereja berperan.

Keyword : Gereja, Kemiskinan, Karl Marx, Spiritualitas

\section{PENDAHULUAN}

Secara etimologis, gereja dikenal dalam bahasa Yunani disebut "Ekklesia" berarti "yang dipanggil keluar”. Gereja juga sering kali didefinisikan sebagai "persekutuan orang-orang percaya" (Andreas, 2010, p. 21). Gereja merupakan kehidupan bersama dari sekelompok orang. Kehidupan bersama semacam ini pada dasarnya merupakan sebuah reali- 
tas sosial yang secara umum dapat dipandang sebagai organisasi atau perhimpunan. Istilah organisasi atau perhimpunan itu biasa dikenal dengan sebutan "persekutuan" atau tepatnya "persekutuan orangorang percaya". Sebagai sebuah organisasi, gereja termasuk dalam kategori organisasi keagamaan (Andreas, 2010, p. 22). Itu berarti bahwa gereja juga merupakan sebuah organisasi yang menyajikan nilainilai keagamaan dengan landasan Alkitabiah.

Kehadiran dan keberadaan gereja di dunia jelas, yaitu untuk berfungsi memuliakan Allah melalui partisipasi aktif dalam mewujudkan tujuan penyelamatan Allah terhadap manusia dan dunia (Andreas, 2010, p. 25). Gereja sebagai institusi/lembaga memiliki peran yang sangat strategis sekaligus tanggung jawab yang besar. Peran strategis tersebut adalah menjadikan gereja sebagai motivator, dinamisator, fasilitator, dan organisator, sehingga warga gereja baik sendiri maupun bersama-sama mampu melakukan upaya pemeliharaan iman. Dengan kata lain, tugas panggilan serta tanggung jawab gereja sebagai lembaga organisasi sosial dan keagamaan, pada dasarnya adalah melakukan pemberdayaan warga gereja melalui program yang sengaja diselenggarakan oleh gereja untuk menjadikan segenap warga gereja mampu memelihara iman mereka (Andreas, 2010, p. 31). Dalam hal ini, merujuk bahwa peran gereja tidak hanya fokus pada iman warga jemaatnya, tetapi bagaimana iman tersebut harus dinyatakan melalui tindakan (action) bukan hanya sekedar iman yang diperkatakan.

Tugas gereja atau kumpulan orang percaya tidak hanya fokus pada iman jemaat, tetapi gereja juga memiliki tugas dan panggilannya. Menilik tritugas gereja yaitu: 1) Bersaksi (marturia). Sebagaimana diperintahkan oleh Tuhan Yesus sebelum Dia naik ke surga adalah menjalankan amanat agungNya (Mat. 28:29). Gereja harus konsisten dalam hal bersaksi, artinya perkataan (verbal) dan perbuatan (nonverbal) mereka harus berjalan searah. Artinya bahwa gereja harus bersaksi melalui perkataan, perbuatan, dan kasih (Yoh. 3:18). (Timotius, 2012, p. 22); 2) Bersekutu (koinonia). Kata Koinonia bukan sekedar menunjuk pada hubungan antara sesama manusia, melainkan juga menyatakan persekutuan antara Allah dan manusia. Istilah ini digunakan dalam (Fil. 1:7), "Aku mengucap syukur kepada Allahku karena persekutuan-Mu (koinonia) sampai sekarang ini”. Gereja sebagai tubuh Kristus merupakan persekutuan orang percaya, yaitu orang-orang yang telah dipanggil keluar (ekklesia). Persekutuan dalam jemaat memungkinkan terjadinya komunikasi sehingga mereka akan saling memahami kebutuhan sesamanya (Timotius, 2012, p. 24); 3) Melayani (diakonia). Melayani adalah perintah Tuhan Yesus Kristus. Hal ini tampak dalam pola hidup Tuhan Yesus, Ia tidak hanya berkhotbah dan mengajak orang, tetapi juga memberikan teladan yang baik dan benar kepada para murid-Nya. Oleh karena itu, gereja juga wajib memberikan pertolongan kepada setiap orang yang memerlukannya dengan membentuk sejumlah komisi untuk mewujudkan tri tugas gereja tersebut. (Timotius, 2012, p. 27). Ketiga hal tersebut di atas, merupakan inti dari tugas dan panggilan gereja di dunia ini. Hal ini seringkali disebut sebagai identitas dan panggilan gereja yang harus di jaga dan dilestarikan. Tri tugas gereja tersebut perlu direfleksikan dan diimplementasikan dalam kehidupan bergereja saat ini.

Dalam jurnalnya, Siswanto (2014) memaparkan sebuah tinjauan teoretis dan teologis terhadap diakonia transformatif gereja. Dalam paparannya membahas berkenaan dengan panggilan gereja terhadap masalah kemiskinan. Pandangan tentang kemiskinan berangkat dari analisisnya dari Alkitab. Kajian yang penulis lakukan lebih mengarah pada pandangan Marx dan pandangan kaum evangelikal tentang kemiskinan. Kajian lainnya dilakukan oleh Marthen Naipupu (2014) menyajikan perihal Pelayanan Kepada Orang Miskin menyajikan model pelayanan diakonia transformatif (Lihat. Widyaatmadja, 2010) yang memosisikan orang miskin sebagai subyek bukan obyek.

Di dalam kajian yang lain ditelisik dari tinjauan biblis, diungkap dalam tulisan Pandangan tentang Kemiskinan dan Kelaparan (Wijaya, 2012) me- 
nyatakan bahwa tidak dibenarkan untuk menyingkirkan orang miskin, karena martabat mereka di hadapan Allah adalah berharga, oleh sebab itu orang miskin perlu dirangkul, dihargai dan dicintai sebagaimana manusia yang lain. Dari beberapa tulisan yang membahas pelayanan dan kemiskinan, kajian dalam tulisan ini untuk melengkapi dengan sajian yang telah ada, dengan mengambil peran bahwa gereja perlu berpihak kepada orang miskin, dengan menyuarakan suara profetisnya, serta melayaninya secara holistik. Bagaimanakah peran gereja dalam mengatasi peliknya permasalahan kemiskinan di tengah masyarakat?

Keberadaan dan kehadiran gereja di tengahtengah masyarakat, sewajarnya memberikan dampak yang positif. Gereja di dalam masyarakat dapat diartikan sebagai suatu organisasi masyarakat sosial, maka dari itu gereja juga harus ikut berpartisipasi dalam menghadapi permasalahan yang terjadi di lingkungan masyarakat sekitar, salah satunya dalam bidang ekonomi. Gereja harus menyadari bahwa masalah ekonomi merupakan masalah yang sangat penting, dan masalah ini tidak hanya menjadi masalah bangsa tetapi juga dunia. Gereja perlu menyadari bahwa masalah tersebut juga merupakan masalah bagi gereja, karena di lain sisi hal tersebut dapat menjadi keresahan bagi jemaat dan masyarakat serta lingkungannya.

Dalam kajian terkait dengan gereja dan masyarakat, tulisan ini akan menjawab pertanyaan bagaimana peran gereja terhadap kemiskinan? Apa yang seharusnya dilakukan gereja terhadap kemiskinan? Pertanyaan tersebut bertujuan untuk memberikan alternatif model pendekatan dan keberpihakan gereja kepada orang miskin.

\section{METODE}

Penulis menggunakan pendekatan kualitatif dengan metode deskriptif analisis. Menurut Sugiyono (2013, p. 64), penelitian deskriptif merupakan penelitian yang dilakukan untuk mengetahui nilai variabel mandiri, baik satu variabel atau lebih (independen) tanpa membuat perbandingan atau dengan menghubungkan antara variabel yang satu dengan variabel yang lainnya. Jenis metode ini digunakan untuk menyajikan data secara menyeluruh dan mendalam terkait dengan literasi terhadap peran gereja di dalam kemiskinan. Obyek kajian dalam penelitian ini meliputi peran gereja dalam masyarakat, khususnya dalam fungsinya kiprahnya memberikan sumbangsih di dalam bidang ekonomi masyarakat.

Tugas dan panggilan gereja akan ditelusuri dalam kajian literatur dan akan berkaitan dengan teori sosial khususnya pemikiran Karl Marx, terkait dengan fakta sosial yang terjadi di tataran praksis. Data yang diperoleh kemudian akan dianalisis menggunakan analisis deskriptif, untuk selanjutnya disajikan dalam sebuah uraian sebagai alternatif solusi pengembangan gereja, dalam kerangka menjawab kebutuhan jemaat secara konkret.

\section{HASIL DAN PEMBAHASAN}

\section{Fakta Sosial}

Masalah kemiskinan seringkali diangkat untuk dijadikan suatu topik bahasan yang menarik dalam seminar-seminar, baik pada tingkat lokal maupun internasional. Hal ini disebabkan karena kemiskinan bukanlah suatu masalah yang dihadapi oleh suatu bangsa, melainkan sudah merupakan permasalahan global. Darmawijaya (1991, p. 5) dalam bukunya yang berjudul Keterlibatan Allah Terhadap Kaum Miskin menyatakan bahwa,

... kemiskinan sebenarnya bukan suatu masalah yang baru, karena sekitar satu abad yang lalu telah didiskusikan dan berbagai kebijaksanaan telah ditempuh untuk mengatasi persoalan kemiskinan. Pada zaman sekarang ini masalah kemiskinan bukanlah masalah yang hanya dihadapi oleh negara dunia ketiga atau hanya kelompok utara-selatan, tetapi sudah menjadi masalah dunia.

Dunia sudah merasakan dampak dari kemiskinan, sehingga banyak orang di berbagai negara berusaha mencari cara guna menyelesaikan masalah kemiskinan.

Pada dasarnya, orang yang dikatakan miskin adalah orang yang serba berkekurangan dalam hidup- 
nya, tidak berharta dan biasa tinggal dan hidup di dalam lingkungan yang kumuh (Widyaatmadja, 2010). Seorang tokoh Theologia Pembebasan dari Peru yang bernama Gustavo Guttirrez menyebut kemiskinan sebaagai suatu "estado escandoloso" atau keadaan tidak terhormat (Yewanggoe, 1992, p. 209). Keadaan orang miskin pada umumnya tidak terhormat dan jauh dari kehidupan khalayak ramai pada umumnya, dan seringkali orang lain enggan bila berkunjung atau bertamu di rumahnya, dikarenakan kondisi lingkungan dan pemukiman yang kumuh tersebut. Berbeda dengan masyarakat Jawa, menurut pandangan mereka yang disebut kemiskinan adalah,

Indikasi kemiskinan bagi masyarakat Jawa adalah (1) rumah reyot, (2) tidak memiliki pakaian yang cukup atau dalam istilah Jawa "klambi resikan' untuk menghadiri pertemuan, (3) tidak memiliki pekerjaan tetap, (4) tidak memiliki persediaan pangan dan (5) tidak memiliki tanah atau ternak besar. (Sutrisno, 1999, p. 41).

Bagi masyarakat Jawa, kemiskinan tersebut adalah menyangkut hal-hal yang bersifat bendawi, yaitu persoalan-persoalan yang berhubungan dengan material saja. Bagi orang-orang Jawa pada umumnya, orang dapat dikategorikan tidak miskin bila kelima hal tersebut di atas terpenuhi dalam hidupnya. Menilik dari kriteria "miskin" ala masyarakat Jawa, terihat bahwa kemiskinan hanya dipandang dari sisi bendawi atau materi saja. Namun, esensi dari kemiskinan yaitu perihal "mental miskin" tidak menjadi titik tolak yang mendasar dalam sudut pandang masyarakat Jawa. Ukuran materi ini yang kemudian berkembang menjadi standar bagi "kemiskinan" di lingkup masyarakat Jawa, bahkan telah pula "diamini" oleh masyarakat secara luas. Konteks kemiskinan inilah yang kemudian perlu diungkap dan diangkat untuk dapat diberikan solusi bagi masyarakat.

Hidup dalam kemiskinan bukanlah suatu impian atau cita-cita dari semua orang. Namun, kemiskinan adalah suatu realitas hidup yang harus dilalui dan dijalani dalam kehidupan manusia. Orang-orang yang hidup dalam kemiskinan seringkali dihindari dan dijauhi oleh kebanyakan orang pada umumnya. Orang-orang yang miskin dipandang sebagai orang yang kotor, kumuh, dan akan tercium bau yang tidak sedap bila berdekatan dengan mereka. Tidak jarang orang-orang miskin akan hidup secara berkelompok dan merasa anti bila bertemu dengan orang-orang yang kaya. Sikap yang berlawanan antara orang miskin dan orang kaya inilah yang menyebabkan kesenjangan sosial dalam kehidupan mereka. Sutrisno (1999, p. 18) memberi pernyataan bahwa, “... ada lima hal yang membuat orang miskin menjadi tidak untung; (1) Kemiskinan (Proverty), (2) Fisik yang lemah (Physical Weakness), (3) Kerentanan (Vulnerability), (4) Keterisolasian (Isolation), (5) Ketidakberdayaan (Powerlessness)." Orang yang mengalami kemiskinan akan menjadi sangat rentan terhadap permasalahan-permasalahan tersebut di atas. Kemiskinan acapkali dinilai sebagai pintu masuk kepaa beragam kejahatan di dalam masyarakat. Banyak orang yang rentan terhadap kemiskinan, berakhir dengan jatuh ke dalam lingkaran kejahatan. Di sisi lain, maju atau tidaknya sebuah masyarakat juga masih di tentukan oleh angka kemiskinan di dalam masyarakatnya.

Perbedaan antara orang miskin dan orang kaya sangat nampak di kota-kota besar. Perbedaan ini akan terlihat dengan sendirinya, dikarenakan orang miskin akan mengelompok sendiri di suatu tempat, lalu mereka membuat pemukiman yang bisa dikatakan ala kadarnya, dalam artian mereka akan membuat rumah dengan tujuan hanya untuk tempat perteduhan saja. Mereka akan membuat rumah dari barang-barang yang ada di sekitarnya tanpa harus membeli bahan-bahan yang mahal. Orang miskin sering menggunakan seng-seng bekas dan kardus-kardus bekas sebagai bahan rumahnya, sehingga pemukiman yang didirikan nampak sebagai tempat kumuh. Dari hal inilah, maka di kota-kota besar akan tampak perbedaan antara yang miskin dengan orang-orang yang hidup di atas garis kemiskinan, melalui lingkungan tempat tinggal mereka.

Di samping lingkungan yang kumuh, kehidupan mereka pun tergolong acak-acakan, dalam artian mereka menjalani hidup tanpa mengenal aturan kesehatan, sehingga tidak jarang bagi mereka menge- 
sampingkan kesehatan tubuhnya, guna mencari uang untuk memenuhi kebutuhan hidupnya dan keluarganya. Oleh karena itu, orang yang hidup dalam kemiskinan seringkali mengalami penyakit-penyakit yang disebabkan kehidupan dan lingkungan yang kumuh. Orang-orang miskin adalah orang yang tidak beruntung dalam hidupnya. Mereka harus menjalani hidup dengan bersusah payah guna mempertahankan dan memenuhi kebutuhan hidupnya.

Kemiskinan dan ketimpangan distribusi pendapatan di antara penduduk merupakan masalah klasik yang dihadapi oleh hampir semua negara sedang berkembang. Seringkali, negara-negara ini dihadapkan pada dilema klasik, orientasi pembangunan hendak dibawa kemana, apakah pertumbuhan ekonomi ataukah pemerataan pembangunan dan pengentasan kemiskinan warganya. Namun kenyataannya, terlepas dari orientasinya, kemiskinan dan ketimpangan pendapatan masih mewarnainya. Kemiskinan merupakan suatu fakta yang dapat ditemui dengan mudah. Tidak perlu mengadakan suatu penelitian yang serius dan mendetail untuk dapat menggambarkan apa itu kemiskinan. Di negara-negara dunia ketiga, seperti Indonesia sekarang ini, kemiskinan dan orang-orang miskin menjadi pemandangan yang paling dominan sejauh mata memandang.

Di Indonesia, sebagaimana sering terjadi di negara sedang berkembang lainnya, fenomena kemiskinan dan ketimpangan pendapatan, bukan sesuatu yang asing, baik di perkotaan maupun pedesaan. Kemiskinan di Indonesia ditandai dengan banyaknya masyarakat yang hidup di lingkungan-lingkungan kumuh serta banyak masyarakat yang masih kurang pendidikannya. Banyak penduduk Indonesia yang masih tinggal di desa-desa hidup dalam keterbelakangan, jauh bila dibanding dengan para penduduk yang tinggal di perkotaan, baik dari segi ekonomi maupun segi pendidikan. Ini merupakan salah satu bukti bahwa masih terjadi ketimpangan di Indonesia. Selain dari pada itu, juga sebuah fakta bahwa bangsa Indonesia masih berada dalam garis kemiskinan.
Pada dasarnya, dari segi geografisnya Indonesia adalah bangsa yang beruntung. Letak Indonesia yang strategis berada di jalur perdagangan internasional. Di samping itu, bumi Indonesia dikaruniai dengan kesuburan alam yang luar biasa. Menurut Boaz Narwastujati sebagaimana dikutip oleh Setio (2002, p. 77) menjelaskan bahwa,

Perekonomian di Indonesia, dari segi geografis terutama dipengaruhi oleh faktor ekonomi terbesar, yaitu faktor agraris atau pertanian, yang didukung dengan luasnya lahan pertanian yang ada di tiap provinsinya. Faktor lain yang menentukan adalah letak Indonesia yang memang strategis karena berada dalam jalur perdagangan laut maupun udara.

Dari pernyataan tersebut nampak bahwa Indonesia adalah negara yang sangat strategis dari segi geografisnya. Jika dilihat dari hal tersebut di atas, maka seharusnya Indonesia tidak berada di dalam golongan negara-negara miskin. Bahkan, tidak seharusnya Indonesia berada pada posisi "juru kunci" sebagai negara miskin, jika dibanding dengan negara Asia lain, khususnya di kawasan Asia Tenggara (Setio, 2002, p. 79). Kondisi yang sangat sulit ini tidak semestiya dialami oleh bangsa yang berada di wilayah yang sangat strategis, ditambah pula dengan kekayaan alam yang luar biasa di dalamnya, seperti halnya Bangsa Indonesia.

Pengentasan kemiskinan bukanlah permasalahan bagi pemimpin bangsa atau orang-orang yang berpengaruh pada suatu bangsa, melainkan juga tanggung jawab setiap elemen masyarakat sebuah bangsa tersebut. Setiap elemen masyarakat yang diberi kelimpahan hendaknya menyadari dan menyisihkan sebagian hartanya bagi orang miskin. Namun, realitanya banyak dari orang mempunyai kelebihan bersikap acuh terhadap pengentasan kemiskinan. Bahkan bila ditelisik lebih dalam, akan ditemukan sebuah fakta sosial bahwa orang yang berada di atas memonopoli orang-orang yang ada di bawah. Lebih tegasnya, orang-orang kaya (penguasa, pengusaha) akan memanfaatkan kondisi ketimpangan sosial ini demi keuntungan dirinya sendiri. 


\section{Fungsi Gereja}

Gereja merupakan sebuah lembaga yang terdiri dari berbagai lapisan masyarakat. Jika menilik dari segi etimologisnya, gereja berasal dari kata ekklesia yang mempunyai arti dipanggil keluar (Napel, 2002, p. 132). Kata gereja sendiri berasal dari terjemahan bahasa Portugis yaitu igreia. Dari segi falsafahnya, gereja merupakan orang-orang yang telah dipanggil keluar dari tengah dunia untuk dijadikan umat Tuhan yang kudus, dan selanjutnya dapat diutus untuk menjadi garam dan terang dunia. Gereja merupakan persekutuan orang-orang yang telah dipanggil keluar untuk menjadi saksi di tengah dunia ini. Ada juga yang mengutip 1 Petrus 2:9 dan didefinisikan sebagai umat yang telah dipanggil dari kegelapan kepada terangnya yang ajaib, untuk memberitakan perbuatan-perbuatan besarnya (Larosa, 2001, p. 9). Dalam hal ini, tersirat bahwa gereja merupakan lembaga yang seharusnya terlibat secara aktif untuk memelihara terciptanya kebenaran, keadilan, perdamaian dan kesejahteraan. Kalau memakai bahasa Paulus dalam Efesus 4:1, maka gereja akan tetap menjadi gereja bila kehidupannya berpadanan dengan panggilannya (Larosa, 2001, p. 7).

Pada perkembangannya, banyak dari gereja telah melupakan tugas dan panggilan utamanya yang lambat laun berubah seakan-akan menjadi alat mendukung penguasa. Gereja dengan dogma dan ajarannya membuat legitimasi para penguasa yang menindas dan tidak menghiraukan orang-orang miskin. Gereja mengajarkan untuk selalu bersyukur dalam keadaan apapun, meskipun tertindas dan berkekurangan. Gereja memberi pengertian bahwa penderitaan di dunia hanyalah sementara dibanding dengan kebahagiaan di surga kelak. Melalui ajaran gereja ini, secara tidak langsung gereja telah melegalkan dominasi penguasa atas orang-orang miskin (orang bawahan). Gereja menghambat terjadinya keadilan dengan ajaran-ajarannya yang membawa orang tertindas untuk tetap menerima keadaannya tanpa berpikir untuk melawan dan keluar dari ketidakadilan tersebut.
Banyak dari gereja yang telah mengadakan kegiatan aksi sosial guna membantu orang-orang yang berkekurangan. Melalui aksi sosial tersebut gereja hanya memberi ikan, setelah bantuan itu habis penderitaan dan kekurangan melilit mereka kembali. Dalam dimensi diakonia, aksi sosial yang dilakukan dikenal dengan istilah diakonia karitatif. Dari kacamata misi, Pendeta Arliyanus Larosa dalam bukunya Misi Sosial Gereja menggolongkan aksi sosial gereja itu dalam misi sosial gereja. Definisi misi sosial gereja adalah usaha yang dilakukan gereja secara sadar dalam mencegah dan mengatasi masalah-masalah yang muncul di tengah masyarakat (Larosa, 2001, p. 9). Namun, gereja hanya sekedar membantu pada kulit luar dari permasalahan tersebut dan tidak memberantas sampai akar permasalahannya. Masalah yang dilihat oleh gereja hanya bertumpu pada bantuan ekonomi semata. Padahal, permasalahan yang terjadi sangat kompleks terkait penindasan ekonomi, politik, sosial sampai pada krisis lingkungan. Gereja sangat kurang berperan secara praksis dalam pembebasan masalah-masalah pemberantasan penindasan ekonomi dan sosial. Bahkan gereja cenderung tutup mata terhadap masalah-masalah penindasan hakhak yang dilakukan si kaya terhadap si miskin. Banyak orang-orang kaya yang mengambil peran penting dalam kehidupan bergereja, sehingga orang kaya yang mengatur kebijakan dan ajaran-ajaran bergereja. Inilah yang menjadi penyebab mengapa gereja hanya mengambil sedikit peran dalam pemberantasan penindasan ekonomi dan sosial. Dari hal ini dapat dilihat bahwa gereja cenderung menjadi alat penguasa untuk melegitimasi sepak terjangnya di dunia ekonomi dan sosial.

\section{Agama Adalah Candu Masyarakat}

Karl Marx merupakan seorang tokoh yang banyak menyoroti tentang korelasi antara agama dan ekonomi. Ia begitu tajam berpendapat bahwa agama merupakan salah satu penyebab alienasi yang terjadi di dalam masyarakat (Marx, 2006). Sebagai sistem kepercayaan yang dibangun di atas basis ekonomi yang melahirkan alienasi, maka agama ikut berperan 
besar dalam proses pengalienasian rakyat (kaum proletar yang mayoritas) sebagai akibat dari dominasi kaum borjuis (kaum pemilik modal). Mereka hanya mendapat upah ala kadarnya dan harus bekerja keras dalam waktu yang panjang tanpa mendapat jaminan kesejahteraan dan kesehatan. Mereka menjadi miskin dan tidak lagi bebas memilih pekerjaan. Dalam hal ini, agama di satu sisi telah mengabdi kepada kepentingan masyarakat elit pemilik modal dan di pihak lain telah memalingkan masyarakat mayoritas (kelas buruh) dari persoalan-persoalan yang melingkupinya dengan doktrin adanya harapan hidup yang lebih bahagia kelak di alam akhirat.

Menurut analisa Marx semasa hidupnya, ia berpandangan bahwa terdapat dua kelas dalam masyarakat, yaitu kaum borjuis dan proletar. Kaum borjuis adalah orang-orang pemilik modal yang menguasai perekonomian rakyat dan kaum proletar yang menjadi buruh bagi kaum borjuis. Kaum borjuis merupakan orang-orang yang memonopoli stabilitas ekonomi dan memonopoli para pekerja. Kaum proletar sendiri merupakan kumpulan para pekerja yang bekerja bagi kaum borjuis. Menurut analisis Marx, para buruh bekerja dengan jam kerja yang panjang, namun mendapat upah yang sedikit. Kelas proletar yang melakukan pekerjaan-pekerjaan kasar dan berat hanya menikmati kekayaan paling sedikit dari apa yang dirasakan kelas borjuis. Oleh sebab itu, kaum proletar mengalami keterasingan di dalam hidupnya. Adapun beberapa keterangsingan tersebut yaitu: 1) Terasing dari dirinya sendiri karena ia telah menjadi objek orang lain. Dirinya telah menjadi komoditas yang dibeli kelas borjuis. Ia terasing dari minatnya, dari kebebasannya dalam memilih, dari kebahagiannya, dan dari perasaan harga dirinya. Hidupnya tertekan oleh dominasi kelas borjuis. Situasi itu seperti yang dikatakan Engel, penafsir pikiran-pikiran Marx: Masyarakat modern sangat keji dalam memperlakukan kaum buruh. Kaum buruh dibawa secara masal ke kota-kota besar, yang udaranya jauh lebih buruk dari udara di tempat asal mereka. Mereka diberikan tempat tinggal yang jauh dari kata layak. Bahkan, ketika mereka berbuat sa- lah, dihalau bagaikan menghardik binatang buas, dan tidak diberikan kesempatan untuk hidup senang dan tenang. Sebab, mereka hanyalah alat produksi bagi kaum penguasa. (Kamil, 2002, p. 121); 2) Terasing dari rumpun (species)-nya sebagai manusia yang bebas berkreasi, yang menjadikan manusia berbeda dengan binatang. Kegiatan produktif buruhburuh upahan ditentukan hanya dengan suatu kebutuhan untuk dapat mempertahankan hidupnya, dan tidak lebih dari itu. Pekerjaan yang pada awalnya untuk menyalurkan kreatifitas, kini hanya sebatas kegiatan untuk pemenuhan kepentingan kalangan borjuis. Mereka hanyalah mengetahui ketundukan pada disiplin pabrik jika mereka ingin selamat. Bekerja tidak lagi menjadi alat kreatifitas, tetapi tujuan kepada kepentingan pemenuhan kebutuhan hidup; 3) Terasing dari hasil produksinya. Kelas buruh memproduksi suatu benda, namun setelah jadi, mereka harus membelinya dengan harga yang mahal. Akhirnya, benda itu pun tidak bisa ia miliki sebagai layaknya orang yang memproduksi. Buruh memproduksi barang-barang mahal, akan tetapi ia tidak dapat menikmati barangnya. Tenaga dan waktunya diperas, akan tetapi ia tidak dapat menikmati hasil produksinya; 4) Terasing dari sesama buruh karena mereka harus bersaing memperebutkan tempat kerja. Lebih memprihatinkan lagi ketika peningkatan efisiensi melalui teknologi yang lebih baik ditambah jumlah buruh yang terus melimpah mengakibatkan jumlah buruh yang dipekerjakan semakin sedikit, sementara harga tawar tenaga mereka pun semakin melemah. Ketika tenaganya melemah, maka ia akan digantikan dengan tenaga baru yang lebih muda dan lebih kuat untuk bekerja. Akibatnya pengangguran dan penurunan gaji pun menjadi mungkin. (Gidden, 1986, p. 36).

Berdasarkan pemikiran Marx, sumber keterasingan kaum proletar adalah sistem ekonomi yang terbentuk, sehingga membuat kaum borjuis dapat memonopoli para proletar. Dalam pengamatan Marx, sistem ekonomipun telah masuk dan mencampuri di ranah agama. Para borjuis telah masuk dan memberi pengaruh kepada pendeta dan rohaniwan yang ada di 
dalam gereja. Para penguasa gereja telah berkolusi dengan kalangan politisi dan pengusaha dalam rangka membantu terpeliharanya situasi eksploitatif. Dalam hal ini, agama bukan hanya sebagai ekspresi ekonomi, tetapi juga secara khas memberi dukungan moral atas kepincangan sosial. Atas dasar ini munculah statement Marx yang fenomenal dengan istilah agama adalah candu bagi masyarakat.

Analisa Marx memandang bahwa agama adalah ideologi yang menyesatkan dan menciptakan sebuah kesadaran palsu (false consciousness). Marx mengemukakan bahwa tekanan agama tradisional pada dunia transenden, non material, dan harapan hidup sesudah mati membantu mengalihkan orang dari penderitaan fisik dan kesulitan materiil dalam hidup ini (Johnson, 1988, p. 136). Sikap nrimo, pasrah, dan pasif pun merupakan sikap bijak yang dianjurkan agama. Kekayaan material, status duniawi, dan kekuasaan dilihat dalam kesadaran agama sebagai ilusi, fana, dan sangat berbahaya bagi kesejahteraan rohani individu serta pahalanya bagi kehidupannya kelak. Maka kemudian kemiskinan diubah menjadi kebajikan dan kekayaan menjadi kemiskinan rohani (Johnson, 1988, p. 136). Secara sarkastik Marx menyindir, pada dasarnya agama merupakan ekspresi penderitaan sosial. Agama adalah keluh kesah warga masyarakat yang tertindas. Agama adalah suatu sentimen dunia yang tak berperikemanusiaan. Sumbangan Marx yang berharga bagi perkembangan dunia pemikiran kegamaan adalah kritiknya yang tajam terhadap fenomena keberagamaan, terutama pesan yang bisa kita ambil bahwa terdapat kemungkinan tercorengnya agama oleh perilaku elit-elit agamawan yang bertindak mengatasnamakan Tuhan atau agama.

Karl Marx mempunyai suatu utopia, yaitu ingin membuat suatu masyarakat tanpa kelas. Ia bercita-cita mempunyai sebuah komunitas yang saling memelihara keadilan dan menjunjung tinggi hak-hak sesama manusia. Melalui kajian teorinya, Marx berusaha mengikis habis dominasi kaum kaya (borjuis) terhadap kaum miskin (proletar), dan menciptakan sebuah masyarakat baru yang sama tingkatannya serta hidup berdampingan tanpa adanya dominasi dari satu kelompok terhadap kelompok lain. Namun, menilik realita sosial yang berkembang di tengah dunia ini, pemikiran Marx hanya sebatas pemikiran utopis semata.

Pada perkembangan zaman sekarang, teori dari Marx cocok digunakan untuk menganalisa peranan gereja terhadap kaum proletar (kaum miskin). Banyak orang dari desa datang ke kota besar untuk mencari penghidupan yang layak. Namun, faktanya para pendatang tersebut terjebak dengan sistem ekonomi di kota besar. Mereka harus bekerja keras demi mendapatkan upah yang habis untuk makan sehari. Alhasil, banyak dari mereka tinggal di pemukiman kumuh dan jauh dari kehidupan yang layak. Menilik fakta sosial demikian, maka timbul pertanyaan "bagaimanakah peranan gereja bagi kaum tersisihkan tersebut?" Apakah gereja ma-sih dipakai sebagai alat penguasa untuk membuat suatu kesadaran palsu melalui ajaran-ajarannya, ataukah gereja menjadi solusi bagi ketimpangan sosial tersebut.

\section{Peranan Gereja di tengah Kemiskinan}

Gereja tidak bisa melepaskan diri dari persoalan kemiskinan yang sedang dihadapi. Justru panggilan gereja adalah terlibat secara aktif dalam memerangi kemiskinan dan ketidakadilan. Orang miskin berarti orang yang berkekurangan, tidak memiliki kemampuan untuk memberdayakan dirinya, dan orang yang lemah. Orang miskin ada karena ketidakadilan yang harus mereka terima akibat kejahatan penguasa atau orang-orang yang memiliki kuasa, dan yang merampas hak-hak yang seharusnya dimiliki. Inilah pemiskinan.

Tugas dan panggilan gereja yang seharusnya adalah untuk menyuarakan ketidakadilan dan penindasan hak-hak orang miskin. Gereja hadir untuk berpihak kepada yang lemah, yang tidak berdaya, yang miskin, dan yang terpinggirkan. Jika gereja tidak memiliki keperpihakan kepada yang lemah, maka kehadiran gereja tidak memiliki makna. Kemiskinan harus ditanggulangi supaya manusia mendapatkan keadilan, harkat dan martabatnya sebagai manusia. 
Apabila menilik keadaan Indonesia sekarang ini, masalah sosial begitu mendominasi kehidupan sebagian besar masyarakat. Kemiskinan, pemiskinan, ketidakadilan, aniaya, pemaksaan kehendak, pelecehan, manipulasi hukum dan begitu banyak kejahatan terjadi di negara ini. Di tengah realitas sosial semacam ini, gereja perlu terlibat untuk menguraikan berbagai masalah tersebut hingga menemukan solusi dan jalan keluar yang terbaik. Jika melihat dari kitab Yeremia 29:7 yang berisi "Usahakanlah kesejahteraan kota ke mana kamu Aku buang, dan berdoalah untuk kota itu kepada TUHAN, sebab kesejahteraannya adalah kesejahteraanmu”, maka dapat dipahami bahwa gereja mempunyai tanggung jawab yang besar terhadap kesejahteraan umat manusia di bangsa ini.

Nabi Yeremia memerintahkan umat Allah di Babel agar melaksanakan misi sosial bagi kesejahteraan manusia yang ada di Babel. Dewasa inipun, gereja perlu memahami contoh kisah Yeremia ini untuk dapat direalisasikan dalam kehidupan di zaman ini. Gereja diperintahkan untuk dapat mengusahakan kesejahteraan seluruh rakyat Indonesia (dalam konteks Indonesia), agar rakyat miskin dapat menikmati kehidupan terbaik seperti yang orang lain dapatkan. Bila semua orang mengalami kesejahteraan, maka dapat diasumsikan kehidupan gerejapun akan mengalami kesejahteraan.

Pada bagian lain, Alkitab dengan jelas memberi contoh teladan dari Yesus sendiri yang termaktub dalam Lukas 4:18,19. Adapun identifikasi dari ayat ini adalah 1) Menyampaikan kabar baik kepada orang miskin; 2) Memberitakan pembebasan kepada orang-orang tertawan; 3) Memberi penglihatan kepada orang buta; 4) Membebaskan orang-orang yang tertindas; 5) Memberitakan tahun rahmat Tuhan sudah datang (Larosa, 2001, p. 14).

Rumusan di atas menggambarkan teladan apa yang dilakukan Yesus di tengah dunianya. Empat dari lima rumusan tersebut berkaitan dengan hal-hal yang banyak disebut orang sebagai hal duniawi, hanya pada bagian akhir Yesus menyatakan hal pembebasan atas dosa yang menyeluruh. Yesus telah memberikan teladan kepada umat-Nya untuk melakuan misi pembebasan yang komprehensif secara holistik. Oleh sebab itu, gereja harus melakukan misinya sesuai dengan misi yang Yesus ajarkan untuk membawa pembebasan kepada umat manusia secara holistik. Gereja harus mendorong jemaat-jemaatnya dan diajar supaya memiliki kepedulian dan kesetiakawanan terhadap orang-orang miskin. Upaya ini bisa dilakukan dengan memberdayakan jemaat untuk saling membantu dan memperhatikan keadaan ekonomi anggota jemaat, serta masyarakat lingkungan sekitar mereka yang mengalami dan merasakan kemiskinan itu.

Jemaat gereja harus didorong untuk hidup dalam kesederhanaan, sebagai wujud rasa solidaritas gereja kepada orang-orang miskin yang masih belum terentaskan di Indonesia. Kesederhanaan itu berarti pula gereja melakukan kritik internal secara terus menerus terhadap berbagai aktivitas dan pelayanannya yang hanya menonjolkan kemeriahan, namun tidak memiliki dampak kepada perubahan sikap dan sensivitas jemaat kepada berbagai persoalan kemiskinan di masyarakat.

Untuk mengatasi persoalan kemiskinan yang sedemikian kompleks dan besar, maka gereja perlu secara proaktif dan rendah hati bersedia bekerja sama dengan umat beragama lainnya untuk menanggulangi kemiskinan. Ini penting agar kehadiran gereja menjunjung harkat dan martabat manusia tanpa membedakan suku, agama dan ras. Inilah panggilan gereja yang utama. Melalui kerja sama yang gereja lakukan, maka kehadiran gereja dapat memberi warna dan memberi makna bagi bersama.

Pada saat yang sama, gereja perlu terus menerus menyuarakan kritik profetisnya tanpa pandang bulu terhadap berbagai penyalahgunaan kekuasaan, terjadinya ketidakadilan, terampasnya hak-hak masyarakat, dan terhadap sistim yang menindas serta memiskinkan manusia. Spiritualitas dan religiusitas jemaat juga harus sampai kepada sebuah kesalehan sosial, di mana energi spiritual yang dimiliki jemaat mampu untuk mendorong kepeduliannya akan berbagai persoalan kehidupan masyarakat. Spiritualitas 
seperti inilah yang harus menjadi perhatian gereja dalam membangun kehidupan jemaat. Salib harus dipahami sebagai refleksi atas penderitaan dan kematian Kristus, namun di saat yang sama pula harus mampu membuka mata dan telinga kita akan penderitaan, kesengsaraan, dan pengharapan manusia akan harkat dan martabatnya sebagai manusia. Disitulah gereja berperan.

\section{Pemberdayaan Jemaat Sebagai Alternatif Solusi}

Pemberdayaan merupakan sebuah alternatif yang dapat dikembangkan oleh gereja. Jemaat bukan hanya mendapatkan ajaran dan ujaran dari Sang Pembawa Firman, akan tetapi lebih dapat diberdayakan untuk dapat berdikari. Tugas holistik gereja menjadi lengkap ketika memasukkan pemberdayaan di dalam fungsi pastoralnya. Seorang tokoh pastoral holistik yaitu Clinebell (1982, p. 101) berpendapat bahwa, "Spiritual growth is the key to all human growth. Because human beings are inherently transpersonal and transcendent, there is no way to fullfill oneself except in relationship to the larger spiritual reality". Dalam hal ini, Clinebell hendak menempatkan agama bukan sebagai lembaga, melainkan sebagai usaha untuk menumbuh-kembangkan kehidupan spiritualitasnya. Agama harus kembali kepada fungsi aslinya, yaitu sebagai sarana pengembalian manusia dalam segi spiritualitasnya, agar membuahkan tingkah laku yang sesuai dengan ajarannya. Lewat pengalaman spiritualitas yang mendalam, seseorang akan mampu menjadikan dirinya sejahtera secara utuh.

Esensi dari spiritualitas bukan hanya tingkat pemahaman tentang Tuhan, melainkan implikasi kehidupan yang mengejawantahkan ajaran Tuhan dalam sikap dan perilakunya setiap hari. Di sinilah tugas dari agama (gereja) untuk dapat memberdayakan jemaat, agar mampu meningkatkan spiritualitasnya, sebagai ketahanan iman dalam meningkatkan presistensi dan eksistensinya dalam memperjuangkan iman di tengah realitas sosial yang ada.

\section{Pandangan Kaum Evangelikal Tentang Kemiskinan}

Membincang permasalahan kemiskinan, kaum evangelikal sangat peduli untuk dalam memberi sumbangsih, baik dalam pemikiran teologis, ataupun dari sisi praksisnya. Secara alkitabiah, diteladankan dalam diri Yesus, bahwa ia mengatakan "Berbahagialah yang miskin di hadapan Allah, karena merekalah yang empunya kerajaan sorga". Konsep ini bukan dimaksudkan bahwa Yesus menyukai seseorang tinggal dalam kemiskinan, tetapi Ia berpihak kepada orang miskin, sampai kerajaan sorgapun memberi perhatian kepada mereka. Keteladanan dari keberpihakan Yesus kepada orang miskin membuat kajian teoretis maupun praksis di kalangan evangelikal terus digaungkan, untuk dapat membantu mengangkat kaum miskin dari keberadaannya.

Secara prinsip, sebagai seorang pengikut Yesus keteladanan Yesus memberikan inspirasi dan impartasi untuk senantiasa digumuli bersama. Sebagai mandataris Tuhan di dunia, dalam praksis bergereja perlu dilandaskan berdasarkan landasan yang benar. Chris Marantika memberikan landasan hidup dalam praksis bergereja yaitu pertama beriman kepada Tuhan, kedua konsep berbagi, ketiga kesatuan, keempat hidup yang memuliakan Allah (Marantika, 2000, p.190). Konsep beriman kepada Tuhan memberikan pengertian bahwa sumber kehidupan ada di dalam tangan Tuhan, tanpa Tuhan sia-sialah kehidupan, apalagi kehidupan bergereja, bila tidak ada Tuhan, di dalamnya bukan lagi disebut gereja, tetapi bisnis gereja. Konsep ini perlu diyakini secara sungguh dalam kehidupan bergereja.

Konsep berbagi memberikan pengertian bahwa sebagai mandataris kerajaan sorga di dunia ini, sudah sewajarnya dapat berbagi, baik secara rohani maupun jasmani kepada sesama manusia. Tuhan Sang Pemberi Hidup sudah membagi hidupnya kepada orang yang percaya kepada-Nya, sudah selayaknya, orang yang menjadi pengikut-Nya membagikan hidupnya kepada orang lain. Prinsip kesatuan memberikan pengertian bahwa gereja diberi kepercayaan menjadi wakil Tuhan di tengah dunia selayaknya da- 
pat bersatu bersama gereja yang lain, sebagai satu tubuh Tuhan dan dalam rangka mengemban tugas yang sama. Di dalam kesatuan tersebut akan memberikan dampak yang signifikan bagi peran dan kiprah gereja di tengah dunia ini. Apabila ketiga hal tersebut telah menjadi prinsip yang kuat di dalam kehidupan bergereja, prinsip yang keempat menjadi lebih mudah dilakukan, karena hidup bergereja bertujuan untuk mempermuliakan Tuhan, bukan tuan.

Keutuhan dalam menjalankan praksis bergereja menjadi titik tolak dalam model pelayanan yang dibangun oleh gereja. Di dalam perannya di tengah dunia ini, gereja bukan saja memberi peran dalam sisi spiritualitas saja, akan tetapi juga mempunyai kewajiban berperan dalam sisi jasmani, dan sisi yang lain di dalam kehidupannya. Herlianto (2012, p.14) menegaskan bahwa kehadiran gereja di tengah dunia bukan saja memberikan kesembuhan secara rohani, tetapi seharusnya memberikan kesembuhan pula secara jasmani. Kedua hal ini merupakan dua sisi mata uang yang tidak dapat dipisahkan, dan menjadi sebuah kesatuan yang utuh. Apabila landasan Firman Tuhan menjadi titik tolak dalam kehidupan bergereja, maka kehidupan spiritual dapat menjadi pondasi yang kuat untuk dapat berdampak memberi kesembuhan secara jasmani pula (Nugroho, 2017, p.150).

Kesembuhan jasmani di sini mempunyai pengertian yang luas, bukan hanya berbicara perihal sakit penyakit, akan tetapi juga merujuk kepada kemiskinan dan pemiskinan. Kebutuhan jasmani menjadi penting untuk disembuhkan, mengingat kemiskinan adalah awal dari kejahatan. Gereja mempunyai peran mengurai permasalahan perihal kemiskinan. Jika menilik keteladanan Yesus, bukan saja dalam khotbah di bukit disebutkan perihal orang miskin, akan tetapi dalam praktiknya Yesus sendiri sangat menolak orang kaya yang memeras orang miskin. Sebagai contoh kisah Zakheus di dalam nats injil Lukas 19:1-10. Dikisahkan, bahwa seorang pemungut cukai (pajak) bernama Zakheus yang menjumpai Yesus dan membagikan separuh hartanya, karena ia telah merampasnya dari orang miskin. Ini merupakan salah satu kisah tentang keberpihakan Yesus ke- pada orang miskin. Banyak yang Yesus kerjakan selama hidupnya baik menolong orang miskin, maupun menghardik orang yang sengaja memiskinkan sesamanya. Keteladanan Yesus yang berpihak kepada orang miskin menjungkirbalikan kebiasaan pada masanya. Pola dunianya memberikan tempat dan ruang bagi orang yang punya. Fasilitas, kemewahan, kemudahan bahkan hak untuk diperlakukan secara adil hanya dapat dinikmati oleh orang yang berada, dan tidak dapat dinikmati oleh orang miskin (Nainggolan, 2011, p.146).

Sikap keberpihakan Yesus sangatlah jelas menjadi dasar dari kaum evangelikal meletakkan praksis kehidupan bergerejanya. Kaum miskin merupakan sesama yang perlu untuk dilayani dan diberikan kesembuhan jasmaninya. Gereja perlu memberikan pelayanan yang menyentuh kehidupan jasmani, dalam bentuk pelayanan yang holistik. Gereja bukan saja berperan secara spiritual saja, tetapi kehidupan spiritual tersebut dijadikan landasan untuk melakukan aksi kepada kaum miskin. Dalam pola pikir di dunia, orang miskin tidak mempunyai ruang untuk mengakses keadilan, kesejahteraan, bahkan keselamatan. Namun, dalam pola pikir Kerajaan Allah orang miskin diberikan tempat yang sama di dalamnya. Gereja perlu berpihak kepada kaum miskin, bukan untuk memberikan motivasi agar bersyukur terhadap keadaannya, melainkan untuk bangkit dan sekaligus berbuat sesuatu, karena Allah ada di pihak mereka (Nainggolan, 2011, p.147). Gereja perlu menyuarakan kepada orang kaya atau penguasa untuk dapat menghargai dan mengasihi kaum miskin sebagai sesamanya. Tidak lagi menginjak, mengeksploitasi, tetapi berbuat adil dalam rangka membantu menyejahterakan hidupnya, dan mempermuliakan Allah dengan mempraktikkan kehidupan yang berbagi dengan sesamanya.

\section{KESIMPULAN}

Gereja yang merupakan mandataris Tuhan di dunia ini. Perannya sebagai mandataris Kerajaan Allah perlu diaktualisasikan, sehingga "rasa" sebagai garam dan terang itu dapat tampak di tengah ma- 
syarakat. Pergumulan hidup masyarakat yang perlu diambil sebagai kajian dalam menetapkan praksis bergereja. Gereja perlu berperan aktif untuk dapat memberikan solusi bagi pergumulan masyarakat. Tidak hanya melakukan aksi sosial, yang tampak membantu sesaat, tetapi perlu usaha transformatif agar dapat memberikan jawaban yang tepat dalam usaha membantu masyarakat.

Kemiskinan merupakan pergumulan masyarakat yang selalu menjadi pemikiran strategis nasional untuk diselesaikan. Senada dengan hal ini, tugas dan panggilan gereja adalah untuk menyuarakan ketidakadilan dan keberpihakan gereja kepada kaum yang tertindas. Menilik dari tulisan Nabi Yeremia pasal 29 ayat 7, secara harfiah jelas bahwa dituntut untuk memberikan kesejahteraan bagi masyarakat dimana kekristenan tersebut ada. Meminjam pemikiran Marx, gereja gagal berfungsi berpihak dan menyejahterakan masyarakat dikarena "diperalat" oleh kaum penguasa, sehingga Khotbah yang disajikan merupa-

\section{DAFTAR RUJUKAN}

Andreas, W. 2010. Manajemen Gereja. Bandung: Bina Media Informasi.

Timotius, S. 2012. Gereja yang Bertumbuh dan Berkembang. Yogyakarta: ANDI.

Sugiyono. 2013. Metode Penelitian Kuantitatif, Kualitatif dan R\&D. Bandung: Alfabeta.

Darmawijaya. 1991. Keterlibatan Allah Terhadap Kaum Miskin. Yogyakarta : Aditya Media.

Yewanggoe, A.A. 1992. Kemiskinan Dan Etos Kerja Masyarakat Indonesia. Jakarta: Yakoma.

Sutrisno, L. 1999. Kemiskinan, Perempuan, Pemberdayaan. Yogyakarta: Kanisius.

Setio, R. 2002. Teologi Ekonomi. Jakarta: BPK Gunung Mulia.

Marx, Karl., 2006. "The Communist Manifesto" terkutip dalam Daniel Kolak \& Garret Thomson.The Longman Standard History of Philosophy.Pearson Longman: New York.

Napel, H.T. 2002. Kamus Teologi. Jakarta: BPK Gunung Mulia. kan "pesanan" dari penguasa, sehinga berita baik yang berasal dari Kerajaan Allah, tidak tersampaikan dengan baik kepada masyarakat.

Dalam pengentasan masalah sosial, terutama menyoal kemiskinan ataupun pemiskinan, sebagai mandataris Tuhan di tengah dunia, gereja perlu senantiasa menyuarakan kritik profetisnya tanpa pandang bulu terhadap praktik penyalahgunaan kekuasaan, yang mengakibatkan ketidakadilan dan membuat sistem yang memiskinankan masyarakat. Peningkatan spiritual di dalam jemaat perlu ditingkatkan, sampai jemaat mempunyai kesalehan sosial dan kepedulian sosial di tengah masyarakatnya. Kesalehan sosial inilah yang kemudian menjadi sebuah praksis bergereja, yang bukan hanya mempunyai spiritualitas kepada Tuhan, tetapi mampu juga merefeksikan spiritualitasnya kepada lingkungan masyarakat di sekitarnya, sehingga masyarakat dapat merasakan Tuhan hadir pula di tengah pergumulannya.

Larosa, A. 2001. Misi Sosial Gereja. Bandung: Yayasan Kalam Hidup.

Kamil, S. 2002. "Pemikiran Karl Marx "Agama Sebagai Alienasi Masyarakat Industri"' Suatu Apresiasi Dan Kritik." Jurnal Universitas Paramadina, 1 (2): 116-133.

Marantika, C. et al. 1990. Menuju Tahun 2000: Tantangan Gereja di Indonesia. Bandung: Pusat Literatur EUANGELION.

Gidden, A. 1986. Kapitalisme dan Teori Sosial Modern. Terjemahan Oleh Soeheba K. dari $\mathrm{Ca}$ pitalism and Modern Social Theory; an Analisis of Writing of Marx, Durkheim, and Max Weber. Jakarta: UIP.

Herlianto. 2012. Pelayanan Sosial Gereja. Jakarta: Yabina.

Johnson, D.P. 1988. Teori Sosiologi Klasik dan Modern, Terj. Robert M.Z. Lawang. Jakarta: PT. Gramedia.

Clinebell, H. 1982. Growth Counseling. Nashville: Abingdon. 
Siswanto, K. 2014. "Tinjauan Teoritis Dan Teologis Terhadap Diakonia Transformatif Gereja." Jurnal Simpson: Jurnal Teologi dan Pendidikan Agama Kristen, 1 (1): 95-120.

Nugroho, F.J. 2017. "Pendampingan Pastoral Holistik: Sebuah Usulan Konseptual Pembi- naan Warga Gereja" Evangelikal: Jurnal Teologi Injili dan Pembinaan Warga Jemaat, 1 (2): 139-154.

Nainggolan, C.B. 2011. "Masalah Kemiskinan dan Kepedulian Gereja." Jurnal Teologi STULOS, 10 (1). 